\title{
An atypical 7Q11.2-Q21.11 deletion in a Williams- Beuren syndome patient
}

\author{
Wei Lu", Yi Yang ${ }^{2}$, Xiao-hong Guo², Lin Yang ${ }^{2}$, Hui-jun Wang², Ren-chao Liu², Yu An², Fei-hong Luo \\ From 7th APPES Biennial Scientific Meeting \\ Nusa Dua, Bali. 14-17 November 2012
}

\begin{abstract}
Aims
Williams-Beuren syndrome (WBS; OMIM no. 194050) is a multisystemic neurodevelopmental disorder caused by a hemizygous deletion of $1.55 \mathrm{Mb}$ on chromosome 7 q11.23 spanning 28 genes. Here we report a patient showing mild WBS physical phenotype, who carries a longer $21 \mathrm{Mb}$ atypical deletion.
\end{abstract}

\section{Methods}

Genomic DNA from the proband was extracted from peripheral blood leukocyte. Karyotype analysis was performed on metaphase cells. Array-based comparative genomic hybridization of DNA from the patient's peripheral blood lymphocytes was performed.

\section{Results}

The proband, a female neonate, is the first child of healthy nonconsanguineous Chinese parents. She was born by uterine-incision delivery with intrauterine distress after 41 weeks of gestation. Her birth weight was $2.4 \mathrm{~kg}$. She showed an distinctive facies including broad brow, periorbital fullness, epicanthal folds, short nose, long philtrum, small jaw and prominent earlobes. The cardiology ultrasound examination showed open foramen ovale without elastin arteriopathy such as supravalvular aortic stenosis, pulmonic stenosis. Her abdominal ultrasound examination showed right Duplicated kidneys. Her Karyotyping was 46, XX, del(7)(q11.1q11.23). We then performed array $\mathrm{CGH}$ for this patient and confirmed the deletion region of $21 \mathrm{Mb}$ from $7 \mathrm{q} 11.2$ to $7 \mathrm{q} 21.11$.

\section{Conclusion}

A deletion of the 7q11.23 chromosomal region is found in approximately $90-95 \%$ of the clinically typical WBS

'Department of Endocrine and Inherited Metabolic Diseases, Children's

Hospital of Fudan University, Shanghai, China

Full list of author information is available at the end of the article patients but in a lower percentage of atypical cases. The commonly deleted chromosomal region has a size of approximately $1.5 \mathrm{Mb}$. However, smaller or longer deletions have also been described in atypical WBS patients. Array CGH analysis can be performed to make sure the location and size of microdeletion and confirmed the diagnosis of patients with mild or atypical physical phenotypes.

\section{Authors' details}

'Department of Endocrine and Inherited Metabolic Diseases, Children's Hospital of Fudan University, Shanghai, China. ${ }^{2}$ Pediatric Research Institute, Children's Hospital of Fudan University, Shanghai, China.

Published: 3 October 2013

doi:10.1186/1687-9856-2013-S1-P161

Cite this article as: Lu et al:: An atypical 7Q11.2-Q21.11 deletion in a Williams-Beuren syndome patient. International Journal of Pediatric Endocrinology 2013 2013(Suppl 1):P161.

Submit your next manuscript to BioMed Central and take full advantage of:

- Convenient online submission

- Thorough peer review

- No space constraints or color figure charges

- Immediate publication on acceptance

- Inclusion in PubMed, CAS, Scopus and Google Scholar

- Research which is freely available for redistribution

Submit your manuscript at www.biomedcentral.com/submit
C Biomed Central

\section{Biomed Central}

(c) 2013 Lu et al; licensee BioMed Central Ltd. This is an Open Access article distributed under the terms of the Creative Commons Attribution License (http://creativecommons.org/licenses/by/2.0), which permits unrestricted use, distribution, and reproduction in any medium, provided the original work is properly cited. 